\title{
Ecofeminist Tendencies in Virginia Woolf, Doris Lessing and Arundhati Roy
}

\author{
Mohammad Kaosar Ahmed, PhD
}

Associate Professor, Department of English Language and Literature, International Islamic University Chittagong, Bangaldesh

\begin{abstract}
Ecofeminists investigate the joint abuse of women and nature, and urge people to give more consideration to the inexorably pulverized condition of women and nature. In the perspective of ecofeminists, patriarchy is the main driver of women persecution just as the nature abuse. Woolf, Lessing and Roy have an identical pursuit with that of ecofeminism. With themes consistent with those of ecofeminists, they attempt to explore the universal relationship between degrading female and nature, and advocate building a brand-new relationship between mankind and nature.
\end{abstract}

Keywords-ecofeminism, ecological consciousness, disadvantaged race, women.

We are the bird's eggs. Bird's eggs, flowers, butterflies, rabbits, cows, sheep; we are caterpillars; we are leaves of ivy and sprigs of wallflower. We are women. We rise from the wave. We are gazelle and doe, elephant and whale, lilies and roses and peach, we are air, we are flame, we are oyster and pearl, we are girls. We are woman and nature.

(Susan Griffin, Woman and Nature: The Roaring Inside Her)

Ecofeminism, a spearheading pattern of Environmentalism, is a variety of feminism. It is a women's liberation basic hypothesis which pushes toward the frontal analysis in the late twentieth century. Naturalist Aldo Leopold's portrayal of "the biotic community," of which "man is... only a member" (204-05) in his milestone 1949 paper, "the Land Ethic," brought the ideas of comprehensive quality and a moral protection from anthropocentris $m$ to the development presently known as deep ecology. By pointing out the verifiable association of "anthropocentrism" to "androcentrism", Val Plumwood makes the move in the direction of ecofeminism, which scrutinizes the idea that people (basically as men) are the ones to define the limits "on nature, to apply their control over it and control it" (22). Caroline Merchant in The Death Of Nature: Women, Ecology, and the Scientific Revolution, proposes that present day science reconceptualized "reality as a machine rather than a living organism" and in doing so "endorsed the domination of both nature and women" (Merchant xviii).

The term "Ecofeminism" was first coined by Francoise d'Eanboune, a French Feminist in Le féminismeou la mort in 1974. It takes from the green development, a worry about the effect of human exercises on the non-human world and from women's liberation, the perspective on humankind as gendered in manners that subordinate, misuse and abuse women (Mallor 15). Karen Warren characterizes Ecofeminism in her paper as:

'Ecological feminist philosophy' is the name of a diversity of philosophical approaches to the variety of different connections between feminism and the environment. These different perspectives reflect not only different feminist perspectives (e.g., liberal, traditional Marxist, radical, and socialist feminism); they also reflect different understandings of the nature, and solution to, pressing environmental problems of women (and other oppressed humans) and the domination of nature. (x-xi)

Ecofeminists advocate setting up another agreeable connection between cultures, genders and man-and-nature. They investigate the joint abuse of women and nature, and urge people to give more consideration to the inexorably pulverized condition of women and nature. In the perspective of ecofeminists, patriarchy is the main driver of 
women persecution just as the nature abuse. With the ending goal of unfurling the idea of patriarchal abuse, ecofeminists think about the connection among people, human and nature, and expects to rejuvenate scholarly examination and stir our ecological consciousness. Ecofeminism principally concentrates on the connections among literature and nature, women and nature, so as to stir individuals' familiarity with ensuring nature and thinking about women and the distraught race.

Lessing's consciousness of ecofeminism can be followed in a large portion of her works in which she mirrors the connection among man and nature, race and race, and man and women. Lessing uncovered ecofeminist thoughts through the possibility of her anxiety for the disadvantaged race, her consideration of the economic wellbeing of women and her intension of keeping a harmonious ecofeminist belief system among man and nature. By the women's characters in her works, Lessing communicates her will to appreciate the general harmony and life freedom and the foundation of ecological ethics dependent on the standard of mutual obligation. Through her worry about the disadvantaged individuals in her African novels and stories and her stress over our planet's future in her science fictions, she reliably demands that differences and diversity ought to be kept up; just along these lines would human be able to keep up harmonious and stable ecosystems.

Lessing's novels demonstrate a checked familiarity with global climate change and manage issues of monstrous drought, desertification, and the melting of glacial fields. Lessing calls attention to that essentially men are in charge of this state of ecology. Human instinct in Lessing's African novels, is put with regards to a world that has come back to the dim times of barbarism. Man's dominance over nature has now brought about annihilating climate change. Lessing's novels affirm that both nature ecology and female ecology are obliterated. In Mara and Dann: An Adventure she makes express reference to men's maltreatment of nature which prompts a changing global climate:

There was a reckless about the ways they used their soil and water.

These were peoples who had no interest in the result of their actions. They killed out the animals. They poisoned the fish in the sea. They cut down forests, so that country after country, once forested, became desert or arid. They spoiled everything they touched. There was something wrong with their brain (381).
Lessing intends to recommend that the abnormal state of contamination of the late twentieth and early twenty-first hundreds of years is the result of men's neglectful conduct with nature. Lessing predicts that that day is not far when we will have an age who will never see

in his life whole forests of healthy trees, but only trees standing in dust, trees dying of dryness, trees that seemed whole and well until you saw a limpness in their leaves and knew that drought was attacking their roots... (Mara and Dann: An Adventure 50-51).

This typical disaster is fundamentally the same as in concepts and circumstances to female predicament. Lessing in Mara and Dann: An Adventure, investigating the environmental concerns and feminist consciousness, demonstrates that the experience of Mara and Dann is really the deconstruction of the adventure of dualism - the deconstruction of gender dualism and the deconstruction of dualism among human and nature. In this novel, Lessing traces her optimal of amicable home which is only equivalent to ecofeminists' last objective. In the perfect home, human and nature, men and women, all live in concordance.

The consciousness of the ecofeminis $m$ is plainly reflected in Lessing's different novels, contradicting to the weight on women and nature under the standard of customary patriarchy perspective on the world. In The Cleft a conviction is passed on through the novel that just when the patriarchy never again considers nature and women as "others" or "Articles", this world could accomplish equilibrium. By telling the historical backdrop of human being's creation and displaying the progressions of connection among men and women, nature and human from a feminist perspective, Lessing has completely uncovered her ecofeminist awareness (Ahmed, "Living in the Middle" 407).

Lessing in The Cleft attempts to utilize the ecofeminist analysis to uncover the unjustified masteries of women and nature by men and human beings under the patriarchal reasonable system. She breaks down of associations among women and nature from the parts of symbol, experience and status. Nature is "feminized", while women are "naturalized"(Ahmed, "Living in the Middle" 405). Her novel Love, Again uncovers what women experience the ill effects of unreasonable treatment both previously and right now which prompts a progression of unequal issues in human society. Through the examination of the deplorable 
destiny of the dark lady Julie, Lessing brings up that patriarchy is the foundation of racial separation and class persecution and this is a similar male controlled society that causes the ecological imbalance between individuals and the general public (Ahmed, "Living in the Middle" 408).

Virginia Woolf is extraordinarily aware of ecofeminism. Her ecofeminist writings welcome the feelings that, in $A$ Room of One's Own, she estimated as essential to the development of a novel. Her presentation of feeling like an establishment for imagination foresees the contentions of ecofeminist ethicists. Ecofeminist Josephine Donovan investigates that Woolf "finds that the dominant strain in contemporary ethics reflects a male bias toward rationality, defined as the construction of abstract universals that elide not just the personal, the contextual, and the emotional, but also the political components of an ethical issue" (147). Donovan situates in Woolfian phenomenology a way to deal with compassion that includes complex, inventive developments, and investigation of nature's expressive language (150-52). In her writing Woolf perceives the interconnection of nature and women without setting up a chain of the importance of mistreatments and divisions; communicates her far-reaching perspective on nature; and further investigates the journey for selfhood and an ecological picture of solidarity through the pulverization of polarities. Breaking the limits in gender and nature, Woolf draws a draft of things to come to the vision of accomplishing harmonious existence with nature (Ahmed, "Living in the Middle" 405).

Froula is of the view that Woolf's ecofeminism is showed however her thoughtfulness regarding "the Garden of Eden" and the female "Chrysalis" development in The Voyage Out which exhibits her affectability to the nature's intensity in female development. We can cite Kant to represent Woolf's utilization of nature: "by creating 'another nature ... out of the material that actual nature gives it', endowed with a 'fulfillment' nowhere found in nature, the artist throws a bridge from nature's realm to the realm of freedom" (13). Froula further opines that for Woolf the word 'Opportunity' does not give a general sense like Kant, for her 'Opportunity' means female emancipation.

Woolf has a holistic perspective on gardens, as locales for discussion, and spots where animal and human exercises, dark and light become obscured, eradicating limits and progressive systems. Woolf's has creative relations to "other people" of nature, putting the accentuation on the limits she sees and periodically crosses. Her diaries provide us that she is relegated by her dad with the assignment of building a back greenhouse at Hyde Park Gate, and figures out how to move a significant part of the work to her all the more ready cultivator sister, Vanessa, who proceeded to make the critical, blended media greenery enclosures of Charleston and to transport them into her compositions and delineations (A Passionate Apprentice 130-31).

In her writing, Woolf speaks to intrusions of the systematic, refined greenhouse. In To the Lighthouse Red hot pokers develop in Ramsay's greenhouse. Walking around the spot, the Ramsay couple is isolated in their considerations: Ramsay thinking about the previous opportunity he would encounter on the far off sand slopes, before turning into the defender of his brood on a decreasing spit of land; and Mrs. Ramsay looking toward the town, wherein social work she discovered the reason, besides her family. The couple swing to the "Way where the silver-green spear-like plants grew" (70). In any case, Mrs. Ramsay is worried because her significant other doesn't see the blooms, because rabbits might destroy her night primroses (71), and because she can't raise the bill for fixing the nursery. Mrs. Ramsay designs blooms for the enormous bed where dahlias as of now develop, suspecting that the knobs that she sends down might not be planted. She arraigns the plant specialist, Kennedy with "Serious laziness... if she stood over him all day long with a spade in her hand, he did sometimes do a stroke of work" (67). Woolf here gives a fine case of her (Mrs. Ramsay's) inconsistent position in connection to benefit along with persecution.

The passing of Mrs. Ramsay, Prue and Andrew exhibit that there are holes in the defensive limits of the Ramsay family that reverberate with the vulnerabilities of the greenhouse. It runs wild in the "time passes" interim, independent of limits of class and partition of species, crucial and some of the time even excellent as a result: "in spring the garden urns, casually filled with wind-blown plants, were gay as ever" (138). Mrs. McNab brings home blossoms, seeing no mischief in this, as the family is probably not going to return. Considering Mrs. Ramsay twisting around her blooms, she laments, "the garden was a pitiful sight now, all run to riot, and rabbits scuttling at you out of the beds" (139). Mrs. McNab and her team at any rate sickle the grass. The mysterious, infinite examiner's concept of "Torpor" keeps up the rational edge on the irregular activities of nature.

Woolf's shows ecofeminist qualities through parody which includes both self-parody and parody of man-centric power connected to nature and chasing. For instance, her "Warboys" journal, that shows us on a significant moth- 
chase in Huntingdonshire, subjects her senior sibling Thoby to a genuine spoof. Logical techniques and the British amusement convention are ensnared in this parody of "the most logical method for getting moths" (A Passionate Apprentice 144).

In "The Death of the Moth," she takes up a commonplace position among inside and out, almost a window. She is composing, however she is likewise mindful to multi dayflying moth, and she goes into its existence by means of hers. The underlying essentialness of this animal-an unassuming, less wonderful "type of moth than the class of night-flyers - is that it shared the same energy which inspired the rooks, the plowmen, the horses, and even, it seemed, the lean bare-backed downs on a mellow midSeptember morning" ("The Death of the Moth" 4). Her build recommends the Gaia idea of the globe as an assembled, living thing. The exposition becomes dismal as Woolf feels sorry for the purposeful furthest reaches of the moth, hitting around into "a solitary sheet of glass, when the wide region of the downs lies outside". Gradually she perceives this dark animal is battling "with death, and it wins her regard" by correcting itself, accomplishing what Woolf develops as a feeling of self-control. While nature's power of death can't be ruled, a corrected position can be accomplished. It was all the all the more moving when the "haycolored" moth is viewed as a disregarded "other:" "when there was nobody to care or to know, this gigantic effort on the part of an insignificant little moth, against a power of such magnitude, to retain what no one else valued or desired to keep, moved one strangely" ("The Death of the Moth" 6).

Demonstrating a feeling of shared vitality, and a developing appreciation for an inconsequential being's battle against the more noteworthy intensity of death, Virginia Woolf builds solidarity athwart distant species. At vital focuses in her composition, which are related to her women's liberation, she addresses misuses and controls of living things, even as she permits their disparities as well as appearing intrusions (Ahmed, "Living in the Middle" 405).

Arundhati Roy also, such as Lessing and Woolf, shows ecofeminist propensities in her works. She contends that there are vital associations between the mastery and abuse of ladies and control and misuse of nature by masculinist strategies and mentalities. As of late, India has seen a good number of ecofeminists who have driven natural causes and developments like Medha Patkar, Mahasweta Devi, and Arundhati Roy. Medha Patkar heads the Narmada Bachao Andolan, a social development comprising of inborn individuals, adivasis, ranchers, hippies and human rights activists against the Sardar Sarovar Dam being worked over the Narmada River in Gujarat, India. Mahas weta Devi, a notable women's activist author, has committed a lot of her activism and writing to the reason for improvement of inborn individuals and their condition in India. Arundhati Roy uses her enthusiastic pen for causes extending from the Narmada Bachao Andolan, to atomic testing in India, and to the help of the separatists' interest for aazadi (opportunity) in Kashmir.

In a large portion of her writing Roy has scrutinized both worldwide and national political and financial strategies and the method of usage of government choices regarding, once more, both present moment and long haul sway on the populace and the earth. An example from one of her papers would demonstrate that her legislative issues have dependably been for the benefit of poor people, for the most part uneducated casualties of natural catastrophes made by huge budgetary organizations and State approaches. In their grasp nature gets comparative mistreatment like women. She expounded on the effect of the Sardar Sarovar Dam on the lives of the residents confronting ousting from the valley in these terms in the unexpectedly titled paper, "The Greater Common Good".

In her most observed The God of Small Things Roy demonstrates a solid parallel that exists between the abuse of women and the control of nature by male centric culture (Ahmed, "Living in the Middle" 444). Recognizing the ecofeminist worry about the interconnected persecutions of sex, race, class, and nature that are controlled into various leveled doubles with socially supported mastery, Roy's The God of Small Things depicts the weakening of the anecdotal town of Ayemenem. She starts her story with a depiction of beautiful scene of Kerala:

May in Ayemenem is hot brooding month. The days are long and humid. The river shrinks and black crows gorge on the bright the mangoes in still, dust green trees. Red bananas ripen. Jackfruits burst. Dissolute bluebottles hum vacuously in the fruity air.... The wild, overgrown garden was full of the whisper and the surrey of lives. In the undergrowth a rat snake rubbed itself against a glistening stone. Hopefully yellow bullfrogs cruised the scummy ponds for mates. A drenched mongoose across the leaf-strewn drive away. (1-2) 
The Ayemenem house and its environment give a universe of every single natural component. We discover people cohabiting with the nonhuman creatures. Roy presents the house as situated in common field that guides the author to give away her natural concerns. The blasted jackfruits, the ripened red bananas, dust green mangoes, overgrown dividers, rodent wind, bullfrogs, moths, winged serpent flies, creepy crawlies, sanctuary elephants, lakes, the waterway, the riverside and so on are explicit to a field and we discover all these non-living creatures are ordering their jobs like the human characters in this novel. Roy had all around handily attempted to bond nature to women in her fiction. It is clear in the part when Chacko gives history exercises to the twins:

....he told them about the Earth Woman. He made them imagine that the earth four thousand six hundred million years old - was a forty-six-year-old woman.... It had taken the whole of Earth Woman's life for the earth to become what it was. (54)

She introduces the disintegration as a moral story for the debasement of the Ipe family. Pappachi (John Ipe) presented his man-centric strength over the mild, agreeable, ungrudging spouse Mammachi. Mammachi's marital life was perpetually fierce and eager. She had been a simple manikin in the hands of her informed spouse. Pappachi was seventeen years older than her and this activated sexual desire in his brain. He was at the very least an intolerant, possessive, self-important, envious, genuine patriarch who takes out his physical control over the hapless spouse and little girl. He halted his better half's violin exercises when her coach gave great comments on her and had gone to a stretch out to break her violin and toss it in the stream. At last to escape from her oppressive spouse Mammachi begins her business the Paradise Pickles and Preserves. Like Ammu scan for solace and comfort in the stream, Mammachi is finding another existence with her pickle processing plant that saved normal items discovering her connection with nature.

Moreover, the contamination of the stream Meenachal and the repossession of the History House as a traveler goal are two of the vital focuses that Roy utilizes in building up the relationship between ecological abuse and gender discrimination.Both Ammu and Meenachal River are the two wretched figures in the fiction who attempted to endure. Ammu had been a casualty of male controlled society like the three ages of ladies delineated in the story. She was the little girl of well off and instructed guardians of a Syrian Catholic family in Ayemenem. Her etymologist father showered his annoyance and dissatisfaction (disillusionment in naming a moth) on little Ammu at whatever point he got an opportunity. Ammu was prohibited from going to school since he felt that it is misuse of cash to instruct young ladies. At the point when Ammu attempted to discover a comfort and solace in her marriage and her twins. When she ends up past her continuance she takes up her children and keeps running back to home, trusting that her folks will acknowledge them. In any case, again she needs to confront the cruel substances of life. Ammu feels tormented by the impassion of her relatives who regards them as undesirable bugs. Chacko, her sibling who has a comparable status of a divorced person is given numerous benefits by the family. His mom showers her adoration for him by making courses of action for the flair women to go into Chacko's room without troubling the other relatives. When they came to think about Ammu's association with Velutha, they were anxious to quiet the entire thing. They bolted up Ammu and chastised her harshly, they had even gone to the reach out to plan to slaughter Velutha finally they had prevailing in it. After death of Velutha in the police custody she goes out and comes to Allepy where she met her deplorable demise in Bharath Lodge. Roy had delineated distinctively the dilemma of Ammu with a perspective on denouncing the male centric strength in the public eye. What mancontrolled society had done to Ammu is like what modernization had done to Meenachal River.

Meenachal River that moves through the territory of Ayemenem had been an encapsulation of frightfulness and magnificence, when the waterway was "grey green with fish in it. The sky and trees in it. And at night, the broken moon in it" (203). Twenty three years back she was flighty, dangerous and the most dominant however at this point she had ended up being a minor contracted lace "it greeted her with a ghastly skull's smile, with holes where teeth had been, and a limp hand raised from a hospital bed" (124). It is only human narrow-mindedness to get more yields from the farmland that prompted the passing of this waterway. "Down river, a salt water barrage had been built, in exchange for the votes from the back waters that opened into the Arabian Sea. So now they had two harvests a year instead of one. More rice for the price of a river" (124). The waterway is presently overflowed with modern waste and household squander. The waterway "smelled of shit, and 
pesticides bought with World Bank loans. Most of the fish had died. The ones that survived suffered from fin-rot and had broken out in boils"(140). The green riverside where once there were trees are currently attacked by human settlements. Be that as it may, similar to the surrendered lady Ammu, who lost her life and her adoration for the impulses and likes of station and class cognizant society and male centric society, the waterway gasped with all the foulness and converges to the ocean.

Roy attempts to tie all of the female characters to nature or aspects in nature, once they are troubled. Baby Kochamma is another female figure who discovers comfort and solace in nature. She never faces any physical oppression from any of the male characters in the fiction yet was sincerely tormented by considerations of Father Mulligan whom she had become hopelessly enamored. Infant Kochamma has a go at everything conceivable to get Father Mulligan. She grasps Roman Catholicism and takes pledges of religious shelter planning to persuade opportunity to be with Father. She left the cloister as her endeavors to draw nearer to Father Mulligan was met with dissatisfaction and in the end goes to United States to think about Ornamental Gardening. There is new essentialness and vitality that we find in Baby Kochamma after her arrival from US. She turns the disposed of front yard of Ayemenem House to a wonderful greenery enclosure that she had numerous guests from removed spots. Like a lion-tamer she has tamed twisting vines and nurtured bristling cacti. She has limited bonsai plants and pampered uncommon orchids.

Woolf, Lessing and Roy intend to give humankind a thought regarding the characteristic ecological impact on human, especially the regular natural consequences for human's conduct or way which goes about as a positive effect on them. Accordingly, individuals who are associated or connected with nature in their day by day life are reluctantly under the influence of nature and natural environment. We moreover discover the closeness among different women and nature, nature is female and therefore women can comprehend and feel indigenous habitat more than men. Women's inclination to nature is not quite the same as other human's feeling. Women, as female characters, have a cozy association with nature on account of nature's gentility; for sure, women are nearer to nature than men. Woolf, Lessing and Roy in their novels show that women in nature more than men can understand her; i.e., nature fulfills them and they identify with nature and nature likewise diminishes human's misery, dullness, dejection, apprehension and stresses, when they are in nature.

\section{REFERENCES}

[1] Ahmed, Mohammad Kaosar. "Living in the Middle of a Whirlwind: A Study of the Gender Issues in the Major Novels of Doris Lessing." Islamic University, 2014.

[2] Ahmed, Mohammad Kaosar. "A Psychoanalytic-Feminist Reading of Martha's 'Battle' with Mrs. Quest in Doris Lessing's Martha Quest." Journal of Arts and Humanities, vol. 3, no. 4, 1 May 2014, pp. 32-39

[3] Ahmed, Mohammad Kaosar. "Ecofeminism: A Feminist Approach to Environmental Ethics." The Independent, 2010.

[4] Donovan, Josephine. "Animal Rights and Feminist Theory." Ecofeminism. Ed. Greta Gaard. 167-94. Print.

[5] Francis, Deepa Mary and Thangaraj. August, 2016 "Arundhathi Roy's The God of Small Things from an Ecocritical view point”. Impact: IJRHAL. Vol 4.Issue.n.pg. 76 -82.Web.10 November, 2016.

[6] Froula, Christine.Virginia Woolf and the Bloomsbury AvantGarde: War, Civilization, Modernity. New York: Columbia UP, 2005. Print.

[7] Leopold, Aldo. A Sand County Almanac, and Sketches Here and There. New York: Oxford University Press 1987. Print.

[8] Lessing, Doris. Mara and Dann, An Adventure. New York: HarperCollins, 1999. Print.

[9] ---. Love, Again. New York: HarperCollins, 1996. Print.

[10] Mallor, Mary. "Introduction". Feminism \& Ecology. New York University Press, 1997, Print.

[11] Plumwood, Val. Feminism and the Mastery of Nature. London; New York: Routledge, 1993. Print.

[12] Roy, Arundhathi. The God of Small Things. New Delhi. IndiaInk, 1997. Print

[13] ---. The Algebra of Infinite Justice. New Delhi: Penguin, 2002. Print.

[14] Warren, Karen. 1996. "Ecological Feminist Philosophies". Vedegylet.n.pg: ix-xxvi.Web.10 November, 2016. Available. http://www.vedegylet.hu./Warren-

Ecofeminism.Overview.

[15] Woolf, Virginia. The Death of the Moth and Other Essays. San Diego: Harcourt, 1942 Print.

[16] ---. Mrs. Dalloway. Annotated and introd. Bonnie Kime Scott. Orlando: Harcourt, 2005. Print.

[17] ---. Orlando. San Diego: Harcourt Brace Jovanovich, 1956. Print.

[18] ---. A Passionate Apprentice: The Early Journals of Virginia Woolf. Ed. Mitchell A. Leaska. London: Hogarth, 1992. Print.

[19] ---. To the Lighthouse. Annotated and introd. Mark Hussey. Orlando: Harcourt, 2005. Print. 